\title{
Efficacy of Fungicides on Grain Mold of Sorghum
}

\author{
Viral Kaushikbhai Desai*, Kalubhai Balubhai Rakholiya and Vijay A. Patil \\ Department of Plant Pathology, N. M. College of Agriculture, Navsari Agricultural \\ University, Navsari-396450, Gujarat, India \\ *Corresponding author
}

Keywords

Sorghum, grain mold, disease incidence, fungicides, yield, disease intensity

Article Info

\section{Accepted:}

18 March 2021 Available Online: 10 April 2021

\section{A B S T R A C T}

Grain mold is economically important disease of sorghum. For Management of sorghum grain mold various chemicals were screened for efficacy and management of grain mold under field conditions. Four different fungicides viz., Hexaconazole, carbendazim, thiram+mancozeb, propiconazole and two control treatments i.e. one water spray and one absolute control were evaluated for control of sorghum grain mold. Among all treatments three spray of propiconazole $25 \%$ ECat $0.025 \%$. was the best treatment with highest grain yield and straw yield at both locations viz., Navsari and Waghai followed by hexaconazole 5\% SC at $0.05 \%$, propiconazole treatment recorded grain yield $(1364.20 \mathrm{~kg} / \mathrm{ha}$.) and stover yield of $(4694.44 \mathrm{~kg} / \mathrm{ha}$.) while hexaconazole treatment recorded grain yield $(1319.44 \mathrm{~kg} / \mathrm{ha})$ and straw yield of $(3765.43 \mathrm{~kg} / \mathrm{ha})$ in pooled mean of both locations. In determination of percent disease incidence (PDI\%) spray of propiconazole $25 \% \mathrm{EC}$ at $1 \mathrm{ml} /$ litre recorded lowest disease incidence in pooled $(3.00 \%)$ followed by hexaconazole $5 \%$ SCat $0.05 \%(3.15 \%)$.

\section{Introduction}

Grain mold disease of sorghum caused due to different micro-organisms. It is a serious disease in sorghum cultivation areas throughout the world. The grain mold disease affects the grains within the ear heads and reduces sorghum yield and quality. The grain mold disease is classified as a major disease among all the sorghum growing areas of world and India depending upon the environmental conditions during growing season. Grain mold of sorghum is classified as major biotic constraint in the cultivation, marketing and utilization of sorghum grains. The disease is particularly important in cultivars and varieties that mature during the humid, tropical and subtropical climates. Usually the term "grain mold" in scientific literature is used to describe the diseased or abnormal 
appearance or colour of the sorghum grains infected due to one or more than one pathogenic fungus. In sorghum, the "Grain Mold complex" is complex of more than 40 genera of fungi that are competent of infecting and colonizing in sorghum grain at all levels of maturity (Little et al., 2012). Various types of losses caused by grain mold include reduction in grain yield, deterioration of seed and grain quality, reduction of remuneration in form of money and reduced marketability of the produce. Damage due to grain mold has been associated with losses in seed mass, grain density, seed germination, storage quality, food and feed processing quality, and market value. The disease sometimes induces premature sprouting of grain in the panicle. Loss of final produce is more because of discoloration of grain and due to yield loss. The yield loss occurs mostly due to reduction in seed size and weight of grain. Some of the mold fungi are producers of potent mycotoxin that are harmful to human and animal health and productivity.

In Kharif season in humid region, the grain mold complex is affecting the productivity and quality causing $30-100 \%$ loss in yield depending on cultivar, time of flowering and surrounding environment conditions during crop maturity to harvesting period (Singh and Bandyopadhyay, 2000). In a survey of economic losses carried out based on all India disease survey data between the years 20012010 It was estimated that the economic losses due to grain mold in case of moderate incidence was Rs. $1452 \mathrm{~kg} / \mathrm{ha}$ and for severe incidence it was Rs. $2323 \mathrm{~kg} / \mathrm{ha}$. The figure for economic losses due to grain mold of sorghum in Gujarat state was Rs.1301 kg/ha. for moderate incidence and Rs.2082 kg/ha. for severe incidence. The total economic losses due to the grain mold disease wasRs. 3150.6 million for moderate incidence and Rs. 5040.7 million in case of severe incidence. (Das and Patil,2015).

\section{Materials and Methods}

Experiments were conducted at farm of N. M. College of Agriculture, Navsari Agricultural University, Navsari and Rajendrapur Farm of Krishi Vigyan Kendra, Waghai (District: Dangs) at Navsari Agricultural University, Navsari during kharif 2016-17. Navsari Agricultural University, Navsari, where the present investigations were carried out situated on co-ordinates $20.9248^{0} \mathrm{~N}$, $72.9079^{\circ} \mathrm{E}$ and situated 13 kilometers away from the seashore of Dandi and has altitude of 9 meters from mean sea level.

Whereas, Waghai is located in theDangs district on coordinates $20.7737^{\circ} \mathrm{N}, 73.4976^{\circ} \mathrm{E}$ and under heavy rainfall zone of south Gujarat where average rainfall is $2500 \mathrm{~mm} /$ year. And has an elevation of 147 meters from mean sea level. The details of procedures adopted in experimentation are described as follows:

\section{Management of sorghum grain mold through fungicides}

Six treatments were applied in the experiment the treatments included four fungicides and two control treatment including one for the water spray and one absolute control i.e., no treatment. Treatment details of fungicides used to control the grain mold of sorghum viz., Hexaconazole 5\% SC, carbendazim $50 \% \mathrm{WP}$, Thiram + mancozeb $75 \%$ WP $(0.2 \%+0.3 \%)$, propiconazole $25 \mathrm{EC}$, water spray and absolute control (no spray).

Three spray of fungicides and Water spray was carried out after initiation of flowering in sorghum crop. The spray was carried out at interval of 15 days. Experiment was carried out with six treatments and four replications and sowing was done at recommended spacing of $45 \mathrm{~cm}$ x $15 \mathrm{~cm}$. The net plot size was $3.60 \mathrm{~m}$ $\mathrm{x} 4.50 \mathrm{~m}$. Sowing and fertilizer application was done as per recommended time and dose. 
Table.1 Effect of fungicides on per cent disease incidence of sorghum grain mold

\begin{tabular}{|c|c|c|c|c|c|}
\hline \multirow[t]{2}{*}{ Sr.no. } & \multirow[t]{2}{*}{ Treatment } & \multirow{2}{*}{$\begin{array}{c}\text { Concentration } \\
(\%)\end{array}$} & \multicolumn{3}{|c|}{ Percent disease incidence (\%)year 2016} \\
\hline & & & Waghai & Navsari & Pooled \\
\hline 1 & Hexaconazole $5 \mathrm{SC}$ & 0.05 & $2.88(1.96)$ & $3.43(2.10)$ & $3.15(7.49)$ \\
\hline 2 & $\begin{array}{c}\text { Carbendazim } 50 \\
\text { WP }\end{array}$ & 0.05 & $4.15(2.26)$ & $3.75(2.17)$ & $3.95(9.47)$ \\
\hline 3 & $\begin{array}{c}\text { Thiram + Mancozeb } \\
75 \mathrm{WP}\end{array}$ & $0.2+0.3$ & $4.98(2.44)$ & $4.23(2.28)$ & $4.60(11.06)$ \\
\hline 4 & $\begin{array}{c}\text { Propiconazole } 25 \\
\text { EC }\end{array}$ & 0.025 & $3.43(2.10)$ & $2.58(1.88)$ & $3.00(7.24)$ \\
\hline 5 & $\begin{array}{c}\text { Control } \\
\text { (Water spray) }\end{array}$ & - & $5.33(2.51)$ & $4.25(2.29)$ & $4.79(11.53)$ \\
\hline 6 & Control (absolute) & -- & $6.48(2.73)$ & $5.48(2.54)$ & $5.98(14.36)$ \\
\hline & S.Em. \pm & & 0.20 & 0.22 & 0.30 \\
\hline & C.D. at $5(\%)$ & & 0.59 & 0.67 & 1.10 \\
\hline & C.V. $(\%)$ & & 8.67 & 11.30 & 7.44 \\
\hline
\end{tabular}

*Square root transformation

Table.2 Effect of fungicides treatment on grain yield and straw yield of sorghum

\begin{tabular}{|c|c|c|c|c|c|c|c|c|}
\hline Sr.no. & Treatment & $\begin{array}{c}\text { Concentration } \\
(\%)\end{array}$ & $\begin{array}{c}\text { Waghai } \\
\text { grain } \\
\text { yield(kg/ha) }\end{array}$ & $\begin{array}{c}\text { Waghai } \\
\text { straw } \\
\text { yield(kg/ha) }\end{array}$ & $\begin{array}{c}\text { Navsari } \\
\text { grain } \\
\text { yield(kg/ha) }\end{array}$ & $\begin{array}{c}\text { Navsari } \\
\text { straw } \\
\text { yield(kg/ha) }\end{array}$ & $\begin{array}{c}\text { Pooled } \\
\text { grain } \\
\text { yield(kg/ha) }\end{array}$ & $\begin{array}{c}\text { Pooled } \\
\text { straw } \\
\text { yield }\end{array}$ \\
\hline 1 & $\begin{array}{c}\text { Hexaconazole } \\
5 \mathrm{SC}\end{array}$ & 0.05 & 1200.00 & 3765.40 & 1370.00 & 3765.40 & 1319.44 & 3765.43 \\
\hline 2 & $\begin{array}{l}\text { Carbendazim } \\
50 \mathrm{WP}\end{array}$ & 0.05 & 1116.00 & 3398.10 & 1324.00 & 4845.60 & 1182.87 & 4121.91 \\
\hline 3 & $\begin{array}{c}\text { Thiram }+ \\
\text { Mancozeb } 75 \\
\text { WP }\end{array}$ & $0.2+0.3$ & 1012.00 & 4123.40 & 1250.00 & 5925.90 & 1168.21 & 5024.69 \\
\hline 4 & $\begin{array}{c}\text { Propiconazole } \\
25 \text { EC }\end{array}$ & 0.025 & 1268.00 & 4666.66 & 1578.00 & 4722.20 & 1364.20 & 4694.44 \\
\hline 5 & $\begin{array}{c}\text { Control } \\
\text { (Water spray) }\end{array}$ & - & 1015.00 & 3969.10 & 722.00 & 2604.90 & 868.83 & 3287.04 \\
\hline \multirow[t]{4}{*}{6} & $\begin{array}{l}\text { Control } \\
\text { absolute }\end{array}$ & -- & 945.00 & 3555.50 & 688.00 & 2478.30 & 800.93 & 3016.98 \\
\hline & S.Em \pm & & 0.23 & 043 & 0.16 & 0.46 & 0.23 & 1.04 \\
\hline & C.D. at $5(\%)$ & & 0.69 & 1.30 & 0.49 & 1.40 & 0.82 & 3.78 \\
\hline & C.V. (\%) & & 25.75 & 13.60 & 17.23 & 14.12 & 16.63 & 10.40 \\
\hline
\end{tabular}


Spray was done at weekly interval after the initiation of disease. The sorghum variety $\mathrm{Gj}$ 42 which is a mid-late variety was used for the experimental trial. Four replications of six treatments were carried out in Randomized block design the plot size was $3.60 \times 4.50$ metre. The outcome was studied in terms of disease incidence and yield. The PDI was calculated using the following formula.

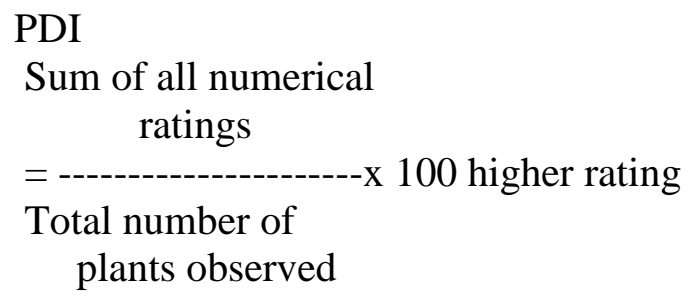

Effect of fungicides spray on grain and straw yield of sorghum

All the fungicides were sprayed three times at the interval of 15 days. Among all the fungicides used to control sorghum grain mold three sprays of propiconazole $25 \mathrm{EC}(0.025 \%)$ at fifteen days interval was the best treatment for control of sorghum grain mold disease incidence and grain and straw yield as shown in Table 2 followed by hexaconazole $5 \mathrm{SC}$ $(0.05 \%)$ all other treatments were lagging behind in control of sorghum grain mold followed by carbendazim 50 per cent W.P., combination of thiram $(0.2 \%)+$ mancozeb $(0.3 \%)$. The results are in confirmation of Audilaxmi et al., (2007) who carried out an experiment during rainy seasons of the years 2000 and 2001 to study the effect of spray treatment of a fungicide they found out that propiconazole $(0.025 \%)$. The result is also in confirmation of Shaik et al., (2019) who conducted two set of experiments simultaneously using naturally and artificially Fusarium challenged induced infected sorghum panicles. The treatment of three sprays of propiconazoleat $0.025 \%$ was the best treatment in terms of grain yield and straw yield at $1364.20 \mathrm{~kg} / \mathrm{ha}$ and $4694.44 \mathrm{~kg} / \mathrm{ha}$ respectively in pooled at both the locations followed by treatment of hexaconazole with grain yield and straw yield of $1319.44 \mathrm{~kg} / \mathrm{ha}$ and $3765.33 \mathrm{~kg} / \mathrm{ha}$ Carbendazim treatment recorded $1182.87 \mathrm{~kg} / \mathrm{ha}$ grain yield and $4121.91 \mathrm{~kg} / \mathrm{ha}$ straw yield. Treatment of Thiram+mancozeb recorded $1168.21 \mathrm{~kg} / \mathrm{ha}$ grain yield and $5024.69 \mathrm{~kg} / \mathrm{ha}$ straw yield followed by controlled water treatment which recorded $868.83 \mathrm{~kg} / \mathrm{ha}$ grain yield and 3287.04 $\mathrm{kg} / \mathrm{ha}$ straw yield and absolute control treatment recorded $800.93 \mathrm{~kg} / \mathrm{ha}$ and grain yield and $3016.98 \mathrm{~kg} / \mathrm{ha}$ straw yield.

\section{Effect of fungicides spray on disease incidence of sorghum grain mold}

The lowest infection scores of 3.0 was recorded with three spray of propiconazoleat $0.025 \%$ spraying at fifteen days followed by 3.15 per cent disease incidence in hexaconazole spray. Carbendazim Thiram+mancozeb, Water spray and absolute control treatments recorded disease incidence in increasing order respectively. Control treatment of Water spray augmented the disease and highest disease incidence was observed in Control treatment with no spray.

\section{References}

Audilakshmi,S.,Aruna,C.,Solunke.,R.B.,Kama tar,M.Y.,Kandalkard,H.G.,Gaikwad,P., Ganeshmurthy,K.,Jayaraj,G.,Ratnavath i,C.V.,Kannababu,N.,Indira,S.,Seethar ama,N. (2007). Approaches to grain quality improvement in rainy season sorghum in India, Crop protection,26: 630-641.

Das,I.K. and Patil, J.V. (2015).Assessment of economic losses due to grain mold of sorghum in India. Compedium of papers and abstracts published by Directorate of sorghum research, 5963.

Little, C. R., Perumal, R., Tesso, T. T., Prom, 
L. K., Odvody, G. N. and Magill, C. W. (2012). Sorghum pathology and biotechnology - A fungal disease perspective: part I. Grain mold, head smut, and ergot. Eur. J. Plant Sci. Biotechnol. 6:10-30.

Shaik,A., Sajeli, B.A., Ragavendra,G., and Pragya,P.P. (2019). Management of sorghum grain mold through induced resistance mechanism using foliar spray of Pseudomonas fluorescens strains and nonconventional chemicals:

a field study. Archives of Phytopathology and Plant Protection, 52 (11-12), 969-988.

Singh S.D. and Bandyopadhyay R. (2000). Grain mold. In: Frederiksen RA, Odvody GN (Eds) Compendium of sorghum diseases ( $2^{\text {nd }} \mathrm{Ed}$.), The American Phytopathological Society, St. Paul, MN, USA. APS Press pp 3840.

\section{How to cite this article:}

Viral Kaushikbhai Desai, Kalubhai Balubhai Rakholiya and Vijay A. Patil. 2021. Efficacy of Fungicides on Grain Mold of Sorghum. Int.J.Curr.Microbiol.App.Sci. 10(04): 648-652. doi: https://doi.org/10.20546/ijcmas.2021.1004.065 